\title{
1. Introduction: legal transplants, convergence and regionalism in Chinese corporate law reform
}

\section{INTRODUCTION AND OVERVIEW}

A number of different approaches have been taken by those who have analysed corporate law reform in China. One group of writers, who can be called 'transplant theorists', have focused on the way in which western concepts of the company have been applied in the drafting of Chinese company and securities legislation. Some have complained of the legal confusion arising from thoughtless transplantation of western company-law concepts into a Chinese political and social context, ${ }^{1}$ while others have seen an auspicious melding of the 'organizational structure of Western capitalist business into a socialist regime'. ${ }^{2}$ Issues of corporate governance preoccupy many of these writers, with several questioning whether mechanisms aimed at overcoming 'agency problems' arising within the western model of the corporation are appropriate for solving possibly different problems, in the different environment of China. ${ }^{3}$

Some analysts of law and corporate governance in China have tried to identify the sometimes confusing variety of foreign influences upon the system, pointing out that, while many aspects appear to have been adapted from civil-law systems such as those of Germany and Japan, still other aspects appear to be based on the example of Hong Kong's success as a common-law based centre of market-oriented business enterprise. Often preoccupied with questions of 'convergence', these writers occasionally hope that future reforms will make the Chinese system more like AngloAmerican systems, and less like those of continental Europe or Japan. ${ }^{4}$

Another group of writers has focused upon the many tensions and fluctuations of power occurring between the centre and the regions in a large country such as China, with some writers even going so far as to predict the eventual breaking up of the 'empire'. ${ }^{5}$ Other observers have not gone so far, but have simply observed the obvious tensions, and examined the emergence of multiple economic, cultural and legal regions within China, ${ }^{6}$ with important consequences for regional approaches to corporate 
law and policy. ${ }^{7}$ Others have emphasized the need to remain aware of differences in the level (central vs regional) and degree (eg. majority owned or controlling minority interest) of state control when analysing management behaviour and firm performance of listed SOEs in China. ${ }^{8}$

This book is influenced by all of these approaches to analysing company law and securities markets in China. It begins, however, with the observation that all equity systems involve a balance of power and obligations shared between government and participants in the securities markets under its jurisdiction. Finding this balance is inevitable, if only because government must determine how, and to what extent, it wishes to regulate the behaviour of the various actors operating in the equities market. It is the state, moreover, which must ultimately enforce the rights and obligations attached to securities traded within its jurisdiction. The way in which powers and obligations are shared between government and the market community is determined by laws and institutions, and these will differ according to the cultural, social and economic conditions in which they emerge.

In mainland China, the defining feature of the equity market must surely be the pervasive presence of the state on both sides of the fence. That is, the state not only provides the rules and institutions within which the securities community must operate, but the state is itself is a major equity stakeholder and participant in the market. ${ }^{9}$ Many writers have pointed out this feature of the Chinese securities markets, and some have also noted that such a feature is not unique to China, but may be typical of developing markets in socialist political systems. ${ }^{10}$ The case studies provided in this book provide an opportunity to explore the implications of this feature of the Chinese system for those Chinese companies which have listed their shares on the Hong Kong Stock Exchange.

$\mathrm{H}$-share enterprises - China-based firms incorporated under mainland laws but with shares listed on the Hong Kong stock exchange - must operate within, and according to, the rules of two very different systems. The Chinese mainland is widely perceived as having an underdeveloped legal system. Likewise, corporate governance standards within Chinaincorporated firms are often seen as either lacking or deficient in their operation. ${ }^{11}$ In sharp contrast to this, Hong Kong is commonly seen as having a well-developed market economy, with a set of regulatory controls and legal safeguards in place derived from Britain that meets western standards. The important point here is that $\mathrm{H}$-share firms inevitably reflect the political, economic and social preoccupations of mainland Chinese governments, yet must at the same time recognize and comply with the demands made by the Hong Kong legal system and securities market. 
Applying the classical evolutionary model from law and economics, two predictions might have been made about the future of the H-share market in China. First, it might have been predicted that corporate governance within $\mathrm{H}$-share firms would reflect the tensions between two different legal systems, and two different ideas of what the corporation is, how it should be managed, and the purposes it should serve. ${ }^{12}$ Successful firms would be those which most efficiently adapted to the sometimes conflicting demands of the Hong Kong securities market, on the one hand, and of the mainland legal, political and economic systems, on the other. In particular, firms which both quickly and selectively adapted their corporate governance structure and practices, taking the most efficient features of each system, would tend to survive.

A second prediction about legal reforms within the H-share market might also have applied the classical evolutionary model from law and economics. According to this model, corporate governance legal reform within the H-share market (and possibly also within publicly-listed Chinese firms in general) would tend to identify and select the most efficient features of the mainland and Hong Kong corporate governance systems. In a globalizing and increasingly connected world, Chinese law makers have also had other corporate governance systems in economically advanced economies to turn to for inspiration. These are typically divided into two basic models: the Anglo-American model centred on the primacy of the market, and the European model centred on the financial intermediary as owner and controller of the firm. In theory, Chinese law makers should have had the luxury of selecting and adapting the most efficient features of both models when developing an indigenous share-market.

What this book demonstrates, however, is that neither of these predictions has been, or is being, fulfilled. Rather, corporate governance practices and corporate governance law reform in China are more accurately viewed as an adaptation to the Chinese political/economic environment. Within individual firms, management decision making has tended to reflect the tensions between often diverging political policy aims of various state agencies involved in ownership and/or oversight of the firm. Likewise, attempts by the Chinese leadership to reform corporate governance standards and practices can be seen as a series of responses to problems that have emerged during the processes of globalization and economic reform. That these responses have not always proved to be the 'best' or most 'efficient' answer to the perceived problem is precisely because of the path-dependent nature of reform. ${ }^{13}$ Saddled with the burden of strong State and Party involvement in every aspect of corporate life, and with the equally heavy burden of local protectionism and the politics of national-provincial rivalries, corporate governance reform in 
China has followed a unique path all of its own, unlike that followed by any other jurisdiction.

The first chapter of this book provides a theoretical background for the legal analysis and case studies which follow. It provides a summary of the way in which 'transplant' theorists such as Watson and others ${ }^{14}$ have analysed and, often prematurely, judged the 'success' or otherwise of attempts to incorporate western ideas of the corporation into Chinese legislation. Some scholars have argued that law reform can serve to initiate or at least facilitate change, such that the future could see management practices and company behaviour in China converging towards those found in western markets.

Another important body of China scholarship emphasizes the importance of regional differences, and the need to avoid nation-wide generalizations in the Chinese context. This scholarship also point to the constantly shifting and widely divergent nature of central-regional relations in China, another feature of the country that pervades nearly all aspects of law and policy. In the case of corporatized and listed SOEs, for example, there may be important differences between those privatized SOEs controlled by central government ministries and those controlled by provincial government authorities. ${ }^{15}$ Protectionist tendencies within provincial government authorities may hinder the implementation of western-style corporate governance law reforms at the company level in some areas, but not in others. Central-regional relations can also determine the extent to which corporatized SOEs in 'strategic' industry sectors are treated differently and managed differently from other enterprises. And as power relations between the centre and the region alter over the years, those shifts and changes may be reflected in changes of company control and management.

Chapter 2 of this book provides an historical overview of the birth and development of the H-share market, beginning with the listing of the first H-share firm, Tsingtao Brewery, in July 1993. In essence, the story told is of a mainland government used to maintaining rigid control over all Chinese enterprises learning how to 'let go', and allow companies to operate according to free ${ }^{\circledR}$ market forces. On the Hong Kong side of the border as well, authorities have experienced a steep learning curve in determining precisely what level of regulatory control is most appropriate for locally-listed mainland firms. What Chapter 2 demonstrates is that the actual selection of the nine mainland firms to be allowed to list 'overseas', and the order of their listing, is a story of tensions between local (regional) power bases and interests on the one hand, and the central government's desire to control the entire process on the other. It is also a story reflecting tensions between the various national-level ministries involved in oversight 
of the strategic industry sectors (such as petroleum) from which the nine vanguard $\mathrm{H}$-share firms were selected. It is this tension between the interests of different state agencies, and the constant negotiations which mediate this tension, that remains a constant feature in the story of Hong Konglisted Chinese firms, especially those listed during the early years of the H-share market.

Chapters 3 and 4 provide a legal and regulatory background for the case studies that follow. In doing so, these chapters reveal two major weaknesses which have characterized and continue to characterize the Chinese regulatory system for listed corporations. First, there is the dispersed and disparate nature of the system, with regulatory control divided between a number of different agencies at different levels of government. As Chapter 3 demonstrates, there is no 'single' regulator of listed companies, either on the mainland or in Hong Kong. In mainland China, the China Securities Regulatory Commission (CSRC) is simply the 'lead' regulator amongst a number of different state agencies at different levels of government (central and regional) each of which is responsible for different aspects of company operations and management. All firms and business enterprises in China, regardless of ownership, are affected to some degree by government policies, both national and local, which are administered through various state supervisory agencies. State policies provide incentives or disincentives (carrots and sticks) that can have a significant effect upon business decision making. Moreover, all firms in China fall under the supervision of at least one (usually more), state ministry to which all proposals for expansion, diversification, re-organization etc. must be submitted for approval. Government policy and funding support for mergers and takeovers, taxrelief and/or funding support for such things as research and development initiatives and new projects, as well as direct government involvement in corporate restructuring initiatives, are just some of the ways in which government policies drive business in China.

The weaknesses inherent in dividing regulatory control amongst different state entities, not all of which have common interests or aims, have only partially been overcome by moves towards centralization of control over listed assets in China. ${ }^{16}$ In the case of $\mathrm{H}$-share enterprises, however, control has always had to be shared with the Hong Kong authorities, primarily the Hong Kong Stock Exchange authority (Hong Kong Exchanges and Clearing Limited, hereafter HKEx) and the Securities and Futures Commission (SFC). For a number of reasons these Hong Kong regulatory agencies are limited in the effectiveness with which they can enforce corporate governance standards, act to protect minority shareholder interests, or otherwise act to impose western-derived norms on Chinese firms. These reasons are explained in Chapter 3 , and include a number of cultural 
and legal obstacles hindering the efficiency of cross-border cooperation between Hong Kong and mainland securities authorities.

The second major weakness inherent in the Chinese regulatory system for listed companies lies in the numerous and overlapping personal relationships between government and management which pervade that system. These are highlighted in Chapter 4, which looks at regulatory reforms in China and Hong Kong specifically aimed at improving corporate governance standards in listed firms. Corporate governance reforms have been aimed both at making listed firms more independent of government, ${ }^{17}$ and at altering the way in which internal aspects of corporate management operate. The noticeable thing about these reforms is the extent to which they appear to have been modelled upon recent reform initiatives in the US, the UK and Australia following a series of corporate collapses that revealed weaknesses in the corporate governance systems of those jurisdictions. The problem is, however, that these jurisdictions are characterized by securities markets with dispersed shareholdings, where shareholders and companies interact on an arm's-length basis. The US, the UK and Australia are all said to have an 'outsider' system of corporate ownership and control typical of Anglo-American legal systems. The same cannot, however, be said of China. Rather, mainland China has obvious features in common with the 'insider' systems of countries such as Japan and Germany. In these systems, shareholdings are more concentrated, and shareholders and creditors are more actively in the control of companies. Reforms aimed at overcoming 'agency' problems and strengthening shareholder rights may well be appropriate in 'outsider' systems, where market efficiency is an importance mechanism for quality control of corporate governance standards. Similar reforms may not, however, be appropriate, or may not achieve the desired objectives, in a different system where different ownership patterns prevail. This raises the possibility that, rather than solving the corporate governance problems of the Chinese listed market (including the $\mathrm{H}$-share market), the current reform process could instead simply serve to disguise the current extent of state control, and allow current problems to be perpetuated.

Chapter 4 of this book also reveals the way in which the interests of the state have been and still are represented within listed Chinese firms. The conclusion is reached that, while protection for minority shareholder interests has improved under recent reforms, it is the State, through a variety of personal allegiances and connections, which remains a dominant presence on the board of most publicly listed Chinese corporations, including those listed in Hong Kong. Personal linkages are possibly the most significant and important aspect of the State's presence in business life in China. This is partly a consequence of state equity ownership, partly due to the paternalism 
of many state policies (especially in strategic industry sectors), and partly a consequence of the current paucity of management experience, training and expertise in mainland China. Even when the non-executive and independent directors (who must now comprise at least one-third of all directors on the board of Hong Kong-listed Chinese companies) are being appointed, firms in China typically turn to government circles to find the necessary level of education and experience. Non-executive directors might come from the local branch of a government-owned bank, for example, or from a local university. The result is a significant overlap between both state and company personnel, although different individuals may be more or less closely involved with different institutions and different state policy concerns. Not surprisingly, changes in the composition of a firm's management personnel often reflect the fluctuating influence of different state organs (eg. central ministry or provincial government authority) over the firm. This creates an environment where the loyalties of company management can be torn in different directions, to the detriment of the company and/or its minority shareholders.

Chapter 5 provides individual case studies of the nine firms chosen to be in the first batch of companies approved for H-share listing. Selected in 1993 to become the first-ever Chinese firms listed outside the mainland, the nine firms were, in order of appearance on the market, Tsingtao Brewery Co. Ltd (Tsingtao) (15.07.93), Shanghai Petrochemical Co. Ltd ${ }^{18}$ (26.07.93), Beiren Printing Machinery Holdings Ltd (06.08.93), Guangzhou Shipyard International Co. Ltd (06.08.93), Maanshan Iron and Steel Co. Ltd (03.11.93), Kunming Machine Tool Co. $\operatorname{Ltd}^{19}$ (07.12.93), Yizheng Chemical Fibre Co. $\operatorname{Ltd}^{20}$ (29.03.94), Tianjin Bohai Chemical Industry (Group) Co. $\operatorname{Ltd}^{21}$ (17.05.94) and Dongfang Electrical Machinery Co. Ltd (06.06.94). What these case studies most obviously reveal is the pervasive influence of the State in almost every aspect of business decision making over the 12 years since the nine firms were listed. This is for several reasons. First, the fact that the State has retained a majority percentage of company equity even after listing has meant that the State, as shareholder, has been able to nominate, and ensure the election of, its own representatives in company management. Second, state policies in the form of both incentives and disincentives (carrots and sticks) have had significant influence, both directly and indirectly, on firm strategy. Direct government involvement in corporate restructuring initiatives has also been used to ensure that firm business strategy accords with state-driven aims and policies.

Strong state involvement in business has a number of consequences, some of which are positive and others negative, when viewed from a traditional business development viewpoint. More importantly for the present context, state involvement in business decision making is neither singular 
nor homogenous. Rather, diverse and disparate versions of the State exist, potentially representing power elites at the local, regional and central government levels, respectively. While tensions exist within each level between diverse departmental aims and interests, the more obvious and influential tensions so far as the nine firms examined are concerned are those between regional (provincial) governments on the one hand, and the national central government on the other.

The case study method as an approach to legal analysis can be justified most when it provides a basis for building a new theory that can then be tested qualitatively at the broader level. ${ }^{22}$ That is precisely what is being attempted here. While many analysts have discussed the (imported western) notion of the corporation when applied to a Chinese context, and others have examined the tensions that exist between the region and the centre in China, no-one has yet applied the idea of tensions between different forms of the state (in particular between regional and national state agencies) to the actual operation of the modern Chinese firm.

The choice of the nine companies examined as the case study sample is justified primarily on the basis that these firms were the very first Chineseincorporated firms to be listed outside China. Selecting these nine firms therefore ensures the longest period of time over which the life of the listed firm can be examined, providing the best opportunity for properly supported conclusions to be reached about their development. What is also true is that the first batch of nine firms was chosen by the Central Government to represent a range of different Chinese industry sectors and regions. This selection was, itself, a political process, as further revealed in Chapter 2. Thus, it is no surprise to find that the nine firms selected to be in the first batch of $\mathrm{H}$-shares were heavily weighted towards heavy industry and manufacturing, reflecting the political influence and economic importance of these sectors in China at the time. ${ }^{23}$

Chapter 6 discusses the role of the market in corporate governance and firm strategy. In particular, this chapter asks whether or not the H-share market can be said to be 'efficient' in the sense that $\mathrm{H}$-share prices respond to information published by, and about, individual firms. What are the implications of the relative lack of liquidity in the H-share market in this context? Reference is made to recent findings by Cheung et al. of 'a positive and significant relationship between CGI [corporate governance index score] and MTBV [market-to-book-value] . . for China-related companies listed in Hong Kong'. Chapter 6 also examines recent reforms to takeover and merger laws in China that are creating a more competitive environment for corporate control. The extent to which the 'disciplinary' effect of the market on firm behaviour is actually strengthened as a result, however, remains to be seen. 
The concluding chapter of this book sums up the complex interrelationships between the various forces operating within and upon China's $\mathrm{H}$-share firms. An examination of these forces reveals that the questions which most preoccupy those who must regulate, advise and make decisions about and on behalf of the H-share firm are questions which arise as a result of the (often conflicting) interests, aims and demands of the regional power élite (local or municipal government) versus those of the central national power élite. A subsidiary thesis is that corporate ownership systems characterized by concentrated shareholdings, in the case of China by concentrated state share-holdings, are not always, or inevitably, inferior to those systems characterized by dispersed shareholdings and greater levels of reliance on the market for finance. Nor are 'insider' systems of corporate control and ownership necessarily less 'efficient' in allowing firms to adapt to market forces.

\section{THEORETICAL BACKGROUND}

\section{A The Story of the Company with Chinese Characteristics}

Many commentators have noted the influence that the principal-agent model of the corporation has had on company law in Anglo-American legal systems. ${ }^{24}$ This model is one which assumes that corporations are run well when directors (agents) make decisions in the 'best interests of' shareholders (principals). When directors fail to do this, inefficient 'agency costs' result. ${ }^{25}$ In order to overcome these agency costs, Anglo-American legal systems give primacy to the interests of shareholders, and impose obligations on company management to exercise their decision-making powers in a manner which furthers the interests of the company and its shareholders. ${ }^{26}$ In contrast to this model of the corporation found in Hong Kong and other Anglo-American jurisdictions, the Japanese and German systems expressly require that stakeholder interests are recognized in corporate decision making. This is achieved essentially through two mechanisms: structural transparency of the corporate form, and participation by stakeholder interests in corporate decision making. The aim is to ensure that the benefits of the corporate form can be fully realized for customers, employees and the community as well as for the shareholder.

In Germany, structural transparency and cooperation in corporate decision making are facilitated by two main features: a two-tiered board structure and a system of co-determination. The two-tiered board system consists of the management or executive board and the supervisory board. ${ }^{27}$ The members of the executive board manage the company and the 
supervisory board members control and monitor the management board. ${ }^{28}$ Independence of the supervisory board is maintained by legislation which provides the two boards with totally separate functions. The system of codetermination operates through the structure and mechanisms of the supervisory board. By requiring that a certain proportion of supervisory board members must be employees, the system ensures that the supervisory board provides a mechanism through which employee representatives can safeguard employee interests. ${ }^{29}$

What light does the 'shareholder vs stakeholder' debate in western corporate theory cast on the history and development of Chinese corporate law? An understanding of variations between models of the corporation, and principles underlying those variations in different western jurisdictions, helps to identify the sources from which different aspects of China's company and securities regime have been borrowed. For example, the twotiered board structure mandated for all listed Chinese firms has clearly been borrowed from the European/ Japanese model of the corporation, while the more recently developed rules aimed, inter alia, at introducing a minimum number of 'independent directors' onto the board of all listed Chinese companies, and empowering those directors in their oversight role, are clearly derived from the United States reforms introduced by SarbanesOxley Act of 2002. In other words, the student of China's legal system needs first of all to understand the extent to which modern Chinese company and securities laws consist of transplanted Western corporation law. The more difficult, but more important task, is then to understand the way in which, in a new cultural context, even the most basic provisions of transplanted law are liable to be interpreted in new and unexpected ways. This involves understanding not just how this process has occurred, but also why the same rule, when 'transplanted' to a different environment, has apparently been interpreted in so many different ways.

\section{B China's Legal System and the Transplant Effect}

Two main themes are discernible in Western legal transplantation discourse. Convergence theorists contend that nation-states are enmeshed in an inevitable and accelerating shift towards internationalization. As telecommunications, urbanization, international investment and international trade increase, regional differences, which in the past inhibited successful legal transplantation, disappear. Convergence theorists have also tended to assume that Western corporate laws, especially those of the United States, both can and should form the model for a global legal template. ${ }^{30}$ The opposing point of view originates from Montesquieu's scepticism that laws cannot traverse cultural boundaries. ${ }^{31} \mathrm{He}$ proposed that laws 
express the spirit of nations and are consequently deeply embedded in, and inseparable from, their geographic, customary and political context. Other scholars have also reached the conclusion that laws are culturally specific and do not transplant with much success, or at least that, to have any hope of being effective, legal transplants must first comprehend and accommodate the ideological, institutional and cultural differences between donor and recipient country. ${ }^{32}$

Other writers have sought theoretical alternatives to the unproductive convergence and cultural-essentialist dichotomy. Otto Kahn-Freund, for example, has found 'degrees of transferability' amongst laws; with some so deeply embedded in their social and institutional matrices as to render transplantation to different cultural contexts virtually impossible, whilst others may be more readily absorbed into different ideological, institutional, social and cultural national legal recipes. ${ }^{33}$ Drawing on this insight, John Gillespie has postulated that

1. The success of legal transplantation is strongly influenced by the congruence between the ideological content of transplanted laws and host country political-legal ideologies. ${ }^{34}$

2. Transplanted law is profoundly influenced by the way institutional structures distribute state power, and the legal cultures (epistemologies) informing official thinking. ${ }^{35}$

3. Certain laws require specific configurations of state and non-state interest groups such as market support organizations (eg. banks, accountants, markets and the media) to function effectively. ${ }^{36}$

The research undertaken for this book provides valuable support for each of these three working postulates. The case studies provided in Chapter 5 also demonstrate the way in which both ideological and institutional aspects of mainland politics have continued to shape firm management decision making, despite exposure to market forces and Western standards of corporate governance via the offshore listing process, and despite recent law reforms on the mainland which appear to incorporate Western ideas of the corporation and corporate governance standards. As Professor Ruskola has also argued, the story of company law reform in modern China is largely a story of the difficulties which state enterprises have had in gaining independence from the politics of state policy determination and administration. ${ }^{37}$

Why should it be so difficult for modern Chinese companies, even those most exposed to foreign markets and influences, to achieve independence from the constraints imposed by mainland ideological and institutional forces? And why should twentieth-century attempts to transplant Western corporations law, and Western ideas of corporate governance, into the 
Chinese context have achieved such limited success? According to Ruskola the reason for this limited success is, at least partly, 'a function of [an] ideology that believes in the fundamental unity of a social and political whole'. ${ }^{38}$ To justify this conclusion, Ruskola points to the differences between the "traditional Chinese view of the corporation as a kinship group' 39 on the one hand, and the individualistic contract-based view of recent Western (American) jurisprudence on the other. According to Ruskola, even when Chinese state enterprises succeed in gaining a degree of independence from the bureaucratic system, their relationship to the bureaucracy is still coloured by familial conceptualizations reminiscent of the rhetoric that defined clan corporations' role within the imperial state. Today, every state entity is supervised by an 'administrative agency in charge' (xingzheng zhuguan bumen), colloquially known as the 'mother company' ( $m$ u gongsi).$^{40}$ In addition, each state entity typically owes a subsidiary duty of loyalty to a number of other administrative units as well. When these other units interfere with enterprise management, the problem is described as having 'too many mothers-in-law (popo duo)'. ${ }^{41}$

Ruskola thus finds that, despite their surface similarities, Chinese and Western corporations' laws are based on diametrically-opposed justifications for a similar entity, the Chinese view being based on a belief in the moral primacy of the collective, while American corporate scholarship has been preoccupied by the need to justify the existence of the corporation in a way that accords with liberal individualism. ${ }^{42} \mathrm{He}$ concludes that the two views are unlikely to converge in a meaningful way 'so long as their legal, political, and discursive interpretations remain informed by distinct local understandings of the nature and purpose of corporations'. ${ }^{43}$

While the 'family' analogy is to some extent justified, Ruskola arguably takes it much too far in discussing the modern Chinese corporation. Certainly, the analogy becomes somewhat strained when discussing large, overseas-listed Chinese corporations. What it does help to highlight, however, is the tensions and 'discontents' that are part of the modern Chinese regulatory system, including the parts of that system aimed at regulating corporate and securities trading behaviour. The reality of different levels of regulatory oversight each representing different political interests is not a matter of kinship-style overlapping relationships. It is quite straightforwardly a matter of political power, and of the way in which political tensions can affect business decisions and corporate behaviour. In particular, a number of writers have pointed to the importance of regional identity and regional protectionism in Chinese political and economic life. How does the 'regionalized' nature of China's regulatory systems, and hence its economy, affect the behaviour of Hong Kong-listed Chinese firms? One hypothesis of this book is that political tensions 
between the region and the centre within mainland China have had a much more significant impact on the behaviour of Hong Kong-listed Chinese firms than have the differences and tensions between Hong Kong and mainland securities law.

\section{Over the Mountain and Far Away: the Centre and the Region in the Chinese Regulatory Experience}

A number of scholars have examined regionalism and the process of decentralization in the Chinese context. Segal, Goodman and others have noted that decentralization, both before and during recent decades of reform since 1978, has caused fault lines to appear in the structure of authority as power has flowed from the central government to the provinces. Historically, China has experienced a number of periods of regional disintegration, most notably during the Warring States period (c. 450-221 BC) and during the Warlord Era of 1916-1928. ${ }^{44}$

So far as the period since 1978 is concerned, David Goodman has argued that 'there is a new pattern of economic regionalism unlike earlier regionalisms experienced in China'. ${ }^{45}$ He points to three key initiatives of the era of economic reform that started with the Third Plenum of the Eleventh Central Committee of the Chinese Communist Party (CCP) in December 1978 which are typically held to have encouraged local political autonomy, and to contain the seeds for potential political disintegration. ${ }^{46}$ One is the decentralization of economic management, which has taken a number of forms. Within the state sector there has been the decentralization of economic management and decision making, with lower levels taking over functions and responsibilities previously the preserve of superior levels. More recently, some of these functions have been reclaimed by central government authorities, reflecting the constant ebb and flow of centre-region tensions which has long characterized China's internal political and economic systems. In addition, governments and the state sector at all levels have divested themselves of large areas of business activity which have now been taken over by private enterprise and by the 'privatized' (formerly state and collectively-owned) sector.

Allied to decentralization is the development of a more market-oriented and market-determined economy. By the early 1990s, few prices were still fixed by the State, and resource allocation decisions were increasingly left to the market. One consequence has been the development of highly localized markets for both supply and distribution. Fiscal decentralization has significantly strengthened the tie between local officials' financial and career rewards and the growth of local government revenue. Efforts to expand the revenue base have led local officials to mobilize resources and 
bend existing rules for local enterprises' market-oriented activities that compete with those promoted by governments in other localities. ${ }^{47}$ Greater provincial autonomy has also allowed provincial leaders to succumb to protectionist instincts in protecting local revenue-generating activities from competition from other provinces. This has been made much easier to achieve against a background of rapid economic growth since the beginning of the reform era. Over the two and a half decades since 1978, China's economy has grown at an annual rate of almost 10 per cent, although, beginning from a small base, its GDP is still only a quarter that of Japan. ${ }^{48}$

Rapid economic growth has also been a result of China's policy of the 'open door' - a policy which has had, possibly unintended, decentralizing consequences as well. Opening up to foreign capital, foreign technology and foreign management expertise has been an integral part of the leadership's drive to modernize the economy and to join (or rejoin) the international economy and the World Trade Organization. As Goodman points out, 'The CCP's determination since the late 1970s to utilize its economic and geographic comparative advantages in the international economic system may also have assisted in the development of a new economic regionalism'. ${ }^{49}$ Although South China, with Guangdong Province being the most obvious example, is in the vanguard, other economic regions are also developing relationships with the international economy outside of China, especially in East Asia. Regions that have been able to develop such relationships no longer depend on central government support or approval for their economic activities. Economic integration between Guangdong and Hong Kong is now such that the movement of goods and people across the border has become virtually unrestricted. Fujian's industrial dependence on Taiwan has been noted by a number of writers. In addition, Japanese, Taiwanese and, since 1992, Hong Kong investment and activities in Jiangsu and Zhejiang have been steadily increasing; Shandong and Northeast China have ties with South Korea and the Russian Far East; Xinjiang is becoming economically integrated with the Turkic republics of the former USSR; and Yunnan's economic relationships with Burma (Myanmar) and Thailand are considerable. ${ }^{50}$

Not surprisingly, therefore, a significant number of observers have concluded that there is 'no threat to the ruling capacity of the central leaders ... more dangerous than the threat of regionalism, which derives from the changes that have occurred in central-regional relations as a result of the economic reforms'. According to these observers, the decentralization of economic functions, which has been essential for carrying out the reforms, has also led to a devolution of political power to such an extent that the capacity of the central government has been brought into doubt. ${ }^{51}$ Some writers have even gone so far as to compare the centrifugal tendencies of 
Chinese Regionalism to those which led to the Soviet Union's recent experience of imploding communism. As Goodman convincingly points out, however, there are a number of reasons why this interpretation is suspect, the analogy strained, and a more subtle understanding of autonomy and regionalism in China is needed..$^{52}$

The cultural determination of regionalism in the PRC is clearly an important factor in relations between the centre and the provinces, most noticeably in the non-Han areas known as 'Autonomous Regions' and concentrated in the border areas of North, Northwest and Southwest China. But even within these areas, separate cultural identity does not necessarily mean political disintegration or provincial separatism. The capacity of the central government to control the regions has always been qualified in China, not least because of China's size, local diversity and the staggering growth of its population in the last century. Even at the heights of its power, central rule has necessarily been limited by decentralization, local autonomy, and some circumvention of central directives. This did not indicate trends towards regionalism in the sense of open and long defiance of the central government by local leaders, who had the capacity to act autonomously on major issues. Instead, departures from central directives have generally been limited. Often, a degree of license in interpreting central directives has even been necessary for the effective operation of China's sprawling political system. ${ }^{53}$

While there may be tensions between the centre and the regions/ provinces, their relationship is by no means necessarily always antagonistic. In the first place, whatever else has happened in the PRC since the start of the reform era in 1978, it remains a Communist Party state. The role of the Chinese Communist Party (CCP) has changed with reform, but it still controls the appointment of senior local leaders, and still exercises that control assiduously, especially at provincial level. ${ }^{54}$ With the possible exception of the major non-Han areas, there are no organizations outside the party-state system that might claim to articulate the wishes of a province or region. Economic development might bring entrepreneurs in a region into conflict with the centre, but that conflict is then mediated by local leaders whose careers depend on their superiors within the CCP, even though they will need to compromise with local demand if they are to ensure compliance with central direction and policy.

In summary, therefore, the position of regional political leadership, as well as the traditions of the CCP which have always encouraged a degree of local flexibility in national policy implementation, have combined to ensure that regionalism has been a constant feature of the PRC's political process and not necessarily a symptom of political disintegration. It is usual to find policies under experimentation regionally before national 
adoption, and central and local leaders frequently combine to lobby on behalf of specific policy initiatives. The relationship between centre and region is then perhaps more usefully interpreted in terms of negotiation rather than conflict. ${ }^{55}$

What happens when negotiations between the centre and the region become the background against which a new type of business enterprise the corporation limited by shares - is created and then expected to strive for economic (business) success? Here I draw on Lin's insight that, 'In the reform era, effective manipulation of state action - ie., making gains from ad hoc favourable treatment by the state - constitutes a necessary condition for the success of firms' in China. When placed against the background of a deliberate policy of fiscal decentralization, what this means is that success for the modern Chinese company depends very largely on management's ability to understand and manipulate the negotiating process between different levels of the State in the effort to attract the most effective form of favourable treatment. The working hypothesis of this book is that this is just as true for the overseas-listed Chinese firm (H-share company) as it is for any other Chinese enterprise.

\section{NOTES}

1. See eg. Teema Ruskola 'Conceptualizing corporations and kinship: comparative law and development theory in a Chinese perspective' [1999-2000] 52 Stanford Law Review 1599-1729, 1705, and Fang Liufang, 'China's corporatization experiment', [1995] 5 Duke Journal of Comparative \& International Law 149-269, 260.

2. Gao Xiqing, 'The perceived unreasonable man - a response to Fang Liufang' [1995] 5 Duke Journal of Comparative \& International Law 271-288; Robert C. Art \& Minkang $\mathrm{Gu}$, 'China incorporated: the first corporation law of the People's Republic of China', (1995) 20 Yale Journal of International Law 273-308.

3. See eg. On Kit Tam, The Development of Corporate Governance in China (Edward Elgar, 1999). Edward S. Steinfeld, Forging Reform in China: The Fact of State-Owned Industry (Cambridge University Press, 1998).

4. See eg. Merton H. Miller, 'Alternative strategies for corporate governance' and Haiying Zhao, 'Restructuring Chinese state-owned enterprises: a contractual approach', in G.J. Wen and D. Xu (eds), The Reformability of China's State Sector (World Scientific, 1996) at 3-16 and 119-130 respectively.

5. See eg. W.J.F. Jenner, The Tyranny of History: The Roots of China's Crisis (Allen Lane Penguin Books, 1992), and see John Fitzerald, 'Reports of my death have been greatly exaggerated: The history of the death of China', in David S.G. Goodman \& Gerald Segal (eds), China Deconstructs: Politics, Trade and Regionalism (Routledge, 1994) 21-58.

6. Jin Huang \& Andrew Xuefeng Qian, "One country, two systems", three law families and four legal regions: the emerging inter-regional conflicts of law in China' [1995] 5 Duke Journal of Comparative \& International Law 289. See also Raymond Wacks, 'One country, Two Grundnormen? The Basic Law and the Basic Norm', in Hong Kong, China and 1997: Essays in Legal Theory (Raymond Wacks, ed., 1993) at 151.

7. For discussion see Dali Yang, 'Reform and the restructuring of central-local relations'; Brantly Womack and Guangzhi Zhao, 'The many worlds of China's provinces: foreign 
trade and diversification' and David S.G. Goodman and Feng Chingyi, 'Guangdong: Greater Hong Kong and the new regionalist future', in David S.G. Goodman \& Gerald Segal (eds), China Deconstructs: Politics, Trade and Regionalism (Routledge, 1994) at 59-98, 131-176 and 177-201, respectively. See also Chi Zhang, Thomas C. Heller \& Michael M. May, 'Carbon intensity of electricity generation and CDM baseline: case studies of three Chinese provinces' [2005] 33 Energy Policy 451-465.

8. See eg. Kin Cheung Liu, 'State control and performance evaluation: The case of a stateowned enterprise in China' (1995) 8:6 International Journal of Public Sector Management 39-50; and Andrew Delios, Zhi Jian Wu and Nan Zhou, 'A new perspective on ownership identities in China's listed companies' (2006) 2(3) Management and Organization Review 319-343.

9. At the end of 1995, State shares made up 54 per cent of the total shares of listed Chinese companies. A number of policies have since ensured a decline in this figure, but as at the end of 2001, the State still owned 47.7 per cent of total shares: Madam Jiang Qianggui (Vice Minister of the State Economic and Trade Commission), 'Speech at the Meeting on Summarizing the Experience of Establishing Modern Enterprise Systems in Listed Companies' (abstract), 27 December 2002. Downloaded from the State Economic and Trade Commission website (http://www.setc.gov.cn.)

10. According to Mark Roe, for example, socialist political systems inevitably produce an 'insider' system of corporate ownership and control. An insider system is said to be one where shareholding is said to be concentrated in the hands of block-holders, and where shareholders and creditors are more actively involved in the control of companies: Mark Roe, 'Political preconditions to separating ownership from corporate control' (2000) 53 Stanford Law Review 539.

11. See eg. Fang Liufang, above n.1, and G.J. Wen and D. Xu (eds), The Reformability of China's State Sector (World Scientific, 1996).

12. For an overview of different views on the nature and purposes of the business corporation, see Lynn A. Stout, 'On the nature of corporations. Symposium: Unincorporation: A New Age?' (2005) 1 University of Illinois Law Review 253 and Lynn Stout, 'On the nature of corporations' (2004) 9(2) Deakin Law Review 775.

13. For a discussion of path dependency, see Mark J. Roe, 'Chaos and evolution in law and economics' [1996] 109 Harv. L. Rev. 641 and see Lucien Arye Bebchuk and Mark J. Roe, 'A theory of path dependence in corporate ownership and governance' (1999) 52 Stanford Law Review 127. See also Randall Peerenboom, 'Globalization, path dependency and the limits of law: administrative law reform and the rule of law in the People's Republic of China' [2001] 19:161 Berkeley Journal of International Law 161.

14. Alan Watson, 'Aspects of reception of law' (1996) 44 American Journal of Comparative Law 335. For overview and discussion of the views put forward by Watson and others, see Richard G. Small, 'Towards a theory of contextual transplants' (2005) 19 Emery International Law Review 1431.

15. For a demonstration of the importance of distinguishing between various sorts of government ownership, see Andrew Delios, Zhi Jian Wu and Nan Zhou, 'A new perspective on ownership identities in China's listed companies' (2006) 2:3 Management and Organization Review 319-343.

16. Since 1998, regulatory control over listed company behaviour has been centralized in the China Securities Regulatory Commission (CSRC) and control over listed state assets has been centralized in the State-owned Assets Supervision and Administrative Commission (SASAC): Leila Fernandez-Stembridge and Jean-François Huchet, 'What's next for China's SOEs?' (2006) 169(5) Far Eastern Economic Review 32, 32-33.

17. Notably, the 'Three Segregations' policy (separation of parent organization and listed company personnel, assets and finance) as implemented in the Public Share Offerings by Listed Companies Tentative Procedures [3710/00.04.30]. Promulgated by the China Securities Regulatory Commission on, and effective as of, 30 April 2000. Translated (July-August 2000) 14(6) China Law \& Practice 45-49. See especially article 4(1).

18. Since re-named Sinopec Shanghai Petrochemical Co. Ltd.

19. Later re-named Jiaoda Kunji High Tech Co. Ltd. 
20. Since re-named Sinopec Yizheng Chemical Fibre Co. Ltd.

21. Since re-named Tianjin Capital Environmental Protection Co. Ltd.

22. See further Robert K. Yin, Applications of Case Study Research (2nd edn, 2003); Robert K. Yin (ed.), Case Study Anthology (2004); Roger Gomm, Martyn Hammersley \& Peter Foster, Case Study Method: Key Issues, KeyTexts (2004); Robert K. Yin, Case Study Research: Design and Method (3rd edn, 2003).

23. What was noticeable about the $\mathrm{H}$-share market even as recently as 2000 was the absence of firms from the services sector. The first Chinese bank, for example, was not listed in Hong Kong until June 2005. By the end of 2006, banking firms make up the largest percentage of the capitalization of the H-share market. Before 2000, however, it was the petrochemical sector which took up most of the market capitalization in the $\mathrm{H}$-share market. For a statistical overview of listed H-share companies, including date of listing and capitalization, see Hong Kong Stock Exchange Website, Data and Statistics, China Dimension, List of H Share Companies, available at http://www.hkex.com.hk/ data/chinadimen/CD_HMB.htm, last updated 30 June 2007, accessed on 5 July 2007.

24. For discussion see Lynne Stout, 'On the nature of corporations' (2004) 9(2) Deakin Law Review 775; Bryan Horrigan, 'Fault lines in the intersection between corporate governance and social responsibility (2002) 25:2 UNSW Law Journal 515; Lucian Arye Bebchuk and Mark J. Roe, 'A theory of path dependence in corporate ownership and governance' (1999) 52 Stanford Law Review 127, and Wayne Gumley, 'Can corporations law reform save the planet? Seeking a missing link between environmental and economic policies', in Gerald Acquaah-Gaisie \& Val Clulow (eds), Enhancing Corporate Accountability: Prospects and Challenges Conference Proceedings, Melbourne, 8-9 February 2006, 239, 243-244.

25. For further discussion, see Michael Spisto, 'Stakeholder interests in corporate governance: Is a new model of governance a change for the better for South Africa? - Part 1', (2005) 18 Australian Journal of Corporate Law 129; D. Bailes, 'Watch your corporation' (1995) 3(1) Journal of Business Law 24; P. Jiang and L.F. Fang (eds), New Corporate Law Textbook, 9th edn (Legal Publishing House, 1998) pp. 48-50, as cited in Y Wei, Comparative Corporate Governance: A Chinese Perspective, Global Trade and Finance Series, Vol. 3 (Kluwer Law International, 2003) 2.

26. Section 181(1) of the Australian Corporations Act, for example, provides that A director or other officer of a corporation must exercise their powers and discharge their duties (a) in good faith in the best interests of the corporation; and (b) for a proper purpose.

The generally-accepted common law test defines 'best interests of the company' to mean the interests of the company's shareholders, or, where a company is insolvent, its creditors: Therese Wilson, 'The pursuit of profit at all costs: corporate law as a barrier to corporate social responsibility' (2005) 30:6 Alternative Law Journal 278, citing Greenhalgh v. Ardene Cinemas [1945] 2 All ER 719 and Kinsela v. Russell Kinsela Pty Ltd (In Liq) (1986) 4 NSWLR 722. See further, Peter Henley, 'Were corporate Tsunami donations made legally?' (2005) 30(4) Alternative Law Journal at 154. See also Parliamentary Joint Committee on Corporations and Financial Services, Australian Parliament, Corporate responsibility: managing risk and creating value (June 2006), available at: http://www.aph.gov.au/Senate/committee/corporations_ctte/corporate_responsibility/report/report.pdf.

27. In German, the Vorstand and the Aufsichtsrat: Spisto, Michael, 'Stakeholder interests in corporate governance: is a new model of governance a change for the better for South Africa? - Part 1', (2005) 18 Australian Journal of Corporate Law 129 at 140.

28. For example, the supervisory board may, inter alia, examine the business decisions made by the management and may examine all financial statements and accounts: ibid.

29. Ibid. 141.

30. See further, John Gillespie, 'Transplanted company law: an ideological and cultural analysis of market-entry in Vietnam' (2002) 51 International \& Comparative Law Quarterly 641; B. Black and R. Kraakman, 'A self-enforcing model of corporate law' (1996) 109(8) Harvard Law Review 1911-82; Sarah Biddulph, 'Through a glass darkly: China, transparency and the WTO' (2001) 3(1) Australian Journal of Asian Law 59, 91-2. 
31. John Gillespie, 'Transplanted company law: an ideological and cultural analysis of market-entry in Vietnam' (2002) 51 International \& Comparative Law Quarterly 641, 644; citing Montesquieu, 1749, De L'Esprit des Lois (The Spirit of Laws), Livre I Gallimard, Paris, reprint J.P. Mayer and A.P. Kerr (eds), (1970). See also Pierre Legrand, 'Comparative legal studies and commitment to theory' (1995) 58 Modern Law Review 263-83; Tahirih V. Lee, 'Risky business: courts, culture and the market place' (1993) 47 University of Miami Law Review 1335, 1338.

32. See eg. Pierre Legrand, 'The impossibility of "legal transplants"' (1997) 4 Maastricht Journal of European and Comparative Law 111, 119.

33. Otto Kahn-Freund, 'On uses and misuses of comparative law' (1974) 37 Modern Law Review 1, 6, 7-11, 27; Otto Kahn-Freund, 'Common law and civil law - imaginary and real obstacles to assimilation', in Mauro Cappelletti (ed.), New Perspectives for a Common Law Europe (1978) 160.

34. John Gillespie, 'Transplanted company law: an ideological and cultural analysis of market-entry in Vietnam' (2002) 51 International \& Comparative Law Quarterly 641, 645-646, citing Robert Gordon, 'Critical legal histories' (1984) 36 Stanford Law Review 65,108 . See also Alan Hunt, 'Dichotomy and contradiction in the sociology of law', in P. Beirne and R. Sharlet (eds), Marxism and Law (1982) 87-89; Maureen Cain, 'Gramsci, the state and the place of law', in David Suggerman (ed.), Legality, Ideology and the State (1983) 111-15; Alan Hunt, 'The ideology of law: advances and problems in recent applications of the concept of ideology to the analysis of law' (1985) 19 Law Society Review $11,13-19$.

35. John Gillespie, 'Transplanted company law: an ideological and cultural analysis of market-entry in Vietnam' (2002) 51 International \& Comparative Law Quarterly 641, citing Pierre Legrand, 'The impossibility of legal transplants (1997) 4 Maastricht Journal of European \& Comparative Law 119. See also Susan Silbey, 'Making a place for a cultural analysis of law' (1992) 17 Law and Social Inquiry 41.

36. John Gillespie, 'Transplanted company law: an ideological and cultural analysis of market-entry in Vietnam' (2002) 51 International \& Comparative Law Quarterly 641, citing Kahn-Freund, 'On the uses and misuses of comparative law' (1974) 37 Modern Law Review 12-14; and Gunther Teubner, 'Legal irritants: good faith in British law or how unifying law ends up in new divergences' (1998) 61 Modern Law Review 30-2.

37. Teema Ruskola, 'Corporations and kinship' (2000) 52 Stanford Law Review 1599, 1693.

38. Ibid. 1693 .

39. Ibid. 1600-1605.

40. Ibid. 1693, citing Fang Liufang, 'China's corporatization experiment' (1995) 5 Duke Journal of Comparative \& International Law 149, 155, n.13.

41. Ibid. 1693-94, citing Donald C. Clarke, 'Regulation and its discontents: understanding economic law in China' (1992) 28 Stanford Journal of International Law 283, 293.

42. Ibid. 1606 .

43. Ibid. 1600 .

44. David S.G. Goodman, 'The politics of regionalism' in David S.G. Goodman \& Gerald Segal (eds), China Deconstructs: Politics, Trade and Regionalism (Routledge, 1994) 3; further noting that it is far from clear that the conditions which have on occasion encouraged a high degree of regionalism in the past are those that apply in the late 20th and early 21 st century.

45. David S.G. Goodman \& Gerald Segal, 'Preface' in David S.G. Goodman \& Gerald Segal (eds), China Deconstructs: Politics, Trade and Regionalism (Routledge, 1994) at viii.

46. David S.G. Goodman, 'The politics of regionalism' in David S.G. Goodman \& Gerald Segal (eds), China Deconstructs: Politics, Trade and Regionalism (Routledge, 1994) 1-20 at 4-5.

47. Yi-min Lin, Between Politics and Markets: Firms, Competition, and Institutional Change in Post-Mao China (Cambridge University Press, 2001) at 5.

48. C.H. Kwan, article written for The Straits Times, accessed 23 November 2004 at http://www.rieti.go.jp/en/. See also Bernard Wasow, 'Should We Trust China', The Globalist, 30 March 2004, available at http://www.theglobalist.com/ and Phil Ruthven, 
'Continued economic growth will make this the Chinese Century', On Line Opinion 17 November 2003, available at http://www.onlineopinion.com.au/.

49. David S.G. Goodman, 'The politics of regionalism' in David S.G. Goodman \& Gerald Segal (eds), China Deconstructs: Politics, Trade and Regionalism (Routledge, 1994) 5.

50. Ibid., 5-6.

51. Ellis Joffe, 'Ruling China after Deng', in Orville Schell and David Shambaugh (eds), The China Reader: The Reform Era (Vintage Books 1999) at 148.

52. David S.G. Goodman, above, n. 49, 5-6.

53. Joffe, above, n. 51, 148.

54. Goodman, above, n. 49, 4.

55. Ibid 